\title{
Humoral immune response in beef heifers supplemented with mineral salt with or without the addition of rumen-protected methionine
}

\author{
Resposta imune humoral em novilhas de corte suplementadas \\ com sal mineral com ou sem adição de metionina protegida da \\ degradação ruminal
}

\author{
Matheus Gomes Lopes ${ }^{1 *}$; José Henrique Echenique Dominguez ${ }^{1}$; Cristina Mendes \\ Peter $^{1}$; Ederson Santos ${ }^{2}$; Paula Almeida Rodrigues ${ }^{2}$; Paulo Ricardo Centeno \\ Rodrigues $^{3}$; Tony Picoli ${ }^{4}$; Marcio Nunes Corrêa ${ }^{5}$; Eduardo Schmitt ${ }^{6}$; Marcelo de \\ Lima $^{7}$; Geferson Fischer ${ }^{8}$
}

\begin{abstract}
The aim of this study was to evaluate the humoral immune response in beef heifers supplemented with mineral supplementation with or without the addition of rumen-protected methionine. Forty-eight Brangus nulliparous heifers were distributed into four experimental groups with three replications each: control group without supplementation and without vaccination (CG01), control group without supplementation and with vaccination (CG02), treatment group with mineral supplementation and vaccination (TG01), and treatment group with mineral supplementation added with protected methionine and vaccination (TG02). The animals were maintained under native pasture with access to water ad libitum and the supplementation was available in high-consumption covered troughs. A supplementation period of 60 days prior to vaccinations was adopted until the first dose of a monovalent experimental vaccine inactivated for BoHV-5 was applied as a method of stimulating the immune response to evaluate the supplementation effects. After a 21-day interval, blood samples were collected to evaluate the humoral response and the second vaccine booster dose was applied following the 21-day interval for new blood samples in order to evaluate the immune response against the two-vaccination protocol. From the beginning of the experiment, the animals were weighed on the days $-60,-10,0$, 21 , and 42 in relation to the vaccine protocol. The experimental groups did not differ for body weight, mean daily weight gain, and body condition score after 102 days of supplementation regardless of the treatment. No animals belonging to CG01 seroconverted throughout the experiment, proving that
\end{abstract}

1 Discentes de Doutorado, Universidade Federal de Pelotas, UFPEL, Pelotas, RS, Brasil. Brasil. E-mail: matheus.lopes.vet@ gmail.com; jdominguez@uol.com.br; cristina_peter@hotmail.com

2 Discentes de Graduação, UFPEL, Pelotas, RS, Brasil. Brasil. E-mail: ederson_santos@ymail.com; paularodrigues201@gmail. com

3 Técnico Administrativo em Educação, UFPEL, Pelotas, RS, Brasil. Brasil. E-mail: priccenteno@hotmail.com

4 Pesquisador PNPD, UFPEL, Pelotas, RS, Brasil. Brasil. E-mail: picolivet@gmail.com

5 Prof. Titular, Núcleo de Pesquisa, Ensino e Extensão em Pecuária, NUPEEC, UFPEL, Pelotas, RS, Brasil. Brasil. E-mail: marcio. nunescorrea@gmail.com

6 Prof. Adjunto, Núcleo de Pesquisa, Ensino e Extensão em Pecuária, NUPEEC, UFPEL, Pelotas, RS, Brasil. Brasil. E-mail: schmitt.edu@gmail.com

7 Prof. Adjunto, Laboratório de Virologia e Imunologia, LABVIR, UFPEL, Pelotas, RS, Brasil. Brasil. E-mail: mdelima.ufpel@ gmail.com

8 Prof. Associado, Laboratório de Virologia e Imunologia, LABVIR, UFPEL, Pelotas, RS, Brasil. Brasil. E-mail: geferson. fischer@gmail.com

* Author for correspondence 
there was no introduction of the agent (BoHV) in the studied area. When vaccinated animals were compared to the CG01 control group, statistically higher levels of neutralizing antibodies $(\mathrm{P} \leq 0.0001)$ and $\operatorname{IgG}(\mathrm{P} \leq 0.0001)$ were verified 21 days after the second vaccine dose. Among the animals of the three vaccinated groups, there was no difference in seroconversion and $\mathrm{IgG}$ production. Therefore, no benefits of mineral supplementation or enriched with protected methionine were observed for the humoral immune response of the studied animals.

Key words: Amino acids. Pampa biome. Immunity. Mineralization.

\section{Resumo}

O objetivo deste estudo foi avaliar a resposta imune humoral em novilhas de corte suplementadas com suplemento mineral com ou sem adição de metionina protegida da degradação ruminal. Quarenta e oito novilhas nulíparas da raça Brangus, foram distribuídas em quatro grupos experimentais com três repetições cada: Grupo Controle sem suplementação e ausente de vacinação (GC01), Grupo Controle sem suplementação e com vacinação (GC02), Grupo Tratamento com suplementação mineral e com vacinação (GT01) e Grupo Tratamento com suplementação mineral adicionada de metionina protegida e com vacinação (GT02). Os animais foram mantidos em pastagem nativa com acesso à água ad libitum e a suplementação disponibilizada em cochos cobertos de alto consumo. Um período de suplementação prévio às vacinações de 60 dias foi adotado até a aplicação da primeira dose de uma vacina experimental monovalente inativada para BoHV-5, como método de estímulo da resposta imune para avaliar os efeitos da suplementação. Após 21 dias de intervalo, foram realizadas coletas de sangue para avaliação da resposta humoral e aplicada a segunda dose de reforço vacinal, seguindo o intervalo de 21 dias para novas coletas de sangue a fim de avaliar a resposta imune frente ao protocolo de duas vacinações. A partir do início do experimento, os animais foram pesados nos dias $-60,-10,0$, 21 e 42 em relação ao protocolo vacinal. Os grupos experimentais, independente do tratamento, não diferiram quanto ao peso corporal, GMD e ECC após os 102 dias de suplementação. Nenhum animal pertencente ao GC01 soroconverteu ao longo do experimento, comprovando que não houve introdução do agente (BoHV) na área estudada. Quando os animais vacinados foram comparados ao grupo controle GC01, níveis estatisticamente superiores de anticorpos neutralizantes $(P \leq 0,0001)$ e de $\operatorname{IgG}(\mathrm{P} \leq 0,0001)$ foram observados 21 dias após a segunda dose vacinal. Entre os animais dos três grupos vacinados, não houve diferença na soroconversão e na produção de IgG. Desta forma, pode-se concluir que não houve benefícios da suplementação mineral ou enriquecida com metionina protegida para a resposta imune humoral dos animais avaliados.

Palavras-chave: Aminoácidos. Bioma pampa. Imunidade. Mineralização.

\section{Introduction}

Strategic supplementation in beef cattle systems has been gaining special prominence in the current national livestock scenario. As the intensification of local agriculture restricts pasture areas available for extensive breeding, measures that enhance forage use are important. Considering that these pastures do not have, in general, all the essential nutritional components in an adequate quantity and quality, mineral supplementation is an important factor for beef cattle and necessary for different metabolic and biochemical processes, including the improvement of the immune response to challenges (MANDAL et al., 2007; HALL et al., 2011).

Another trend in the current market for supplementation is the rumen-protected amino acids (WEISS, 2019). With the improvement in the formulation of ruminant diets, the concept of metabolizable protein was consolidated as an important basis in the evaluations. Due to the essentiality of certain amino acids such as methionine for this species associated with its limitation in forages with low protein levels, strategies that increase its availability by protecting 
against ruminal degradation shows promising results (WATERMAN et al., 2012).

Nutritional balance is an important modulator of immune function. Diets influence immunity by means of substrates necessary for defense cells, besides direct regulatory effects on them. Important mineral and protein substrates, such as amino acids, are required for the anabolic activity of leukocytes, such as leukocyte proliferation and antibody production (PAUL; DEY, 2015). Studies carried out by Osorio et al. (2013) showed that dairy cows supplemented with rumen-protected methionine presented increases related to the productive performance and increased phagocytic capacity of polymorphonuclear cells. When the benefits of these nutrients are investigated through dietary supplementation in beef cattle, few studies have addressed this possible correlation (CLEMENTS et al., 2017). Also in dairy farming, recent studies have been focusing on increasing innate immune response (ZHOU et al., 2018), but little is elucidated on the effects of these strategies against the humoral immune response.

Confirming the importance of minerals and amino acids in the physiological processes of the immune response and development of ruminants, studies that demonstrate these relationships in beef cattle still need to be developed. Therefore, this study aimed to evaluate the effects of a mineral supplement with or without the addition of rumenprotected methionine on the humoral immune response in beef heifers.

\section{Material and Methods}

\section{Experimental station}

The experiment was conducted at an experimental station located in the central-western region of Rio Grande do Sul $\left(30^{\circ} 14^{\prime} \mathrm{S}, 54^{\circ} 36^{\prime} \mathrm{W}\right)$ and approved by the Ethics Committee on Animal Use of the Federal University of Pelotas, RS, Brazil, under the registration number 4514-2017. Through the certification of the international organization Alianza del Pastizal ${ }^{\circledR}$ (BirdLife International, Cambridge, UK), the experimental station is part of the South American natural pasture conservation initiative, in which the native forage species prevalent in the area included Andropogon lateralis, Aristida laevis, Axonopus affinis, Paspalum plicatulum, and Paspalum notatum.

\section{Selection of animals}

A total of 48 Brangus heifers (5/8 Angus x 3/8 Brahman), nulliparous, $14.00 \pm 2.00$ months old, weight of $268.18 \pm 24.45 \mathrm{~kg}$, and body condition score (BCS) of $2.85 \pm 0.27$ were used. The animals were selected according to breed, age, body weight, $\mathrm{BCS}$, seronegative against bovine herpesvirus (BoHV) by means of the seroneutralization technique, and free from persistent infection by the bovine viral diarrhea virus (BVDV) by means of the direct ELISA (Idexx BVDV Ag/Serum Plus, Idexx Laboratories, Westbrook, USA). Previously, all the animals were submitted to preventive management against parasitoses, with the subcutaneous application (SC) of $1 \%$ moxidectin $\left(\right.$ Cydectin $^{\circledR}$, Zoetis, Parsippany-Troy Hills, USA) at a dose of $0.20 \mathrm{mg} \mathrm{kg}^{-1}$. Heifers remained triply identified by numbered earrings with specific coloration for each experimental group, individual digital identification chips, and ear tattooing.

\section{Experimental design}

An experimental area of 24 ha was subdivided into twelve paddocks of 2 ha, allowing the distribution of heifers randomly into four treatments with three replications each, with an animal load of 1.2 $\mathrm{AU} \mathrm{ha}^{-1}$, where one animal unit (AU) corresponds to $450 \mathrm{~kg}$ (SANTOS et al., 2009). Four animals were included per replication, totaling twelve animals per experimental group, according to the following distribution: control group without supplementation and absence of vaccination 
(CG01), control group without supplementation and with vaccination (CG02), treatment group with mineral supplementation (Brasão Pampiano ${ }^{\circledR}$, Brasão do Pampa, São Gabriel, Brazil) and vaccination (TG01), and treatment group with mineral supplementation (Brasão Pampiano ${ }^{\circledR}$, Brasão do Pampa, São Gabriel, Brazil) added with protected methionine (Smartamine ${ }^{\circledR}$ M, Adisseo, Antony, France) and with vaccination (TG02).
The animals were maintained under native pasture with access to water ad libitum and supplementation available in high-consumption covered troughs with $0.50 \mathrm{~m}$ per animal, according to the experimental group. As recommended by the manufacturers, supplement formulations were adjusted for a mean daily intake of $100 \mathrm{~g}$ per animal per day. At fifteenday intervals, troughs were emptied for determining the dry matter (DM) and mean daily intake (MDI). The composition and ingredients of the diets are shown in Table 1.

Table 1. Minerals and ingredients of diets in the different experimental groups.

\begin{tabular}{lcccc}
\hline Ingredient & CG01 & CG02 & TG01 & TG02 \\
\hline Native pasture & Ad libitum & Ad libitum & Ad libitum & Ad libitum \\
Calcium & - & - & $150 \mathrm{~g} / \mathrm{kg}$ & $150 \mathrm{~g} / \mathrm{kg}$ \\
Phosphorus & - & - & $55 \mathrm{~g} / \mathrm{kg}$ & $55 \mathrm{~g} / \mathrm{kg}$ \\
Sodium & - & - & $50 \mathrm{~g} / \mathrm{kg}$ & $50 \mathrm{~g} / \mathrm{kg}$ \\
Sulfur & - & - & $10.5 \mathrm{~g} / \mathrm{kg}$ & $10.5 \mathrm{~g} / \mathrm{kg}$ \\
Zinc & - & - & $2100 \mathrm{mg} / \mathrm{kg}$ & $2100 \mathrm{mg} / \mathrm{kg}$ \\
Manganese & - & - & $525 \mathrm{mg} / \mathrm{kg}$ & $525 \mathrm{mg} / \mathrm{kg}$ \\
Copper & - & - & $420 \mathrm{mg} / \mathrm{kg}$ & $420 \mathrm{mg} / \mathrm{kg}$ \\
Iodine & - & - & $31.5 \mathrm{mg} / \mathrm{kg}$ & $31.5 \mathrm{mg} / \mathrm{kg}$ \\
Cobalt & - & - & $15.8 \mathrm{mg} / \mathrm{kg}$ & $15.8 \mathrm{mg} / \mathrm{kg}$ \\
Selenium & - & - & $10.5 \mathrm{mg} / \mathrm{kg}$ & $10.5 \mathrm{mg} / \mathrm{kg}$ \\
Lasalocid sodium & - & - & $1800 \mathrm{mg} / \mathrm{kg}$ & $1800 \mathrm{mg} / \mathrm{kg}$ \\
Methionine & - & - & - & $40 \mathrm{~g} / \mathrm{kg}$ \\
\hline
\end{tabular}

A supplementation period of 60 days prior to vaccinations was adopted in the treatment groups until the vaccine protocol with the first dose of a monovalent vaccine inactivated for BoHV-5 was applied as a method of stimulating the immune response to evaluate the effects of supplementation. After a 21-day interval, blood samples were collected to obtain blood serum and evaluation of the humoral response generated from the first vaccination. At this time, the second booster dose was applied with the same monovalent vaccine for BoHV-5, following the 21-day interval for new blood collection to evaluate the immune response to BoHV-5 with two doses. The collections of material for bromatological analyses were performed by a single observer on the days -60 (D-60), 0 (D0), and 42 (D42) of the experimental period. The recommended technique was the total availability, as proposed by McMeniman (1997), and the results are shown in Table 2.

Body weight, mean daily weight gain (MDG), and body condition score (BCS)

From the beginning of the experiment, the animals were weighed on the days $-60(\mathrm{D}-60)$, -10 (D-10), 0 (D0), 21 (D21), and 42 (D42) in a digital weighing system $\left(\mathrm{XR} 3000^{\circledR}\right.$, Tru-Test, Porto 
Alegre, Brazil), with fasting of solids and liquid of at least 12 hours. At the time of leaving the restraining chute, heifers were evaluated for body condition score (BCS) according to the adaptation of the methodology proposed by Lowman et al.
(1973), considering the suggested condition score on a scale from 1 (very thin) to 5 (very fat). The mean daily weight gain (MDG) was obtained by the difference in weight of animals between weighings, divided by the number of days in the period.

Table 2. Values of crude ash (CA), ethereal extract (EE), crude protein (CP), neutral detergent fiber (NDF), and acid detergent fiber (FDA) as percentage of dry matter (DM) at the three moments of pasture collection on the days -60 , 0 , and 42 in relation to the vaccine protocol.

\begin{tabular}{lccc}
\hline & \multicolumn{3}{c}{ Days } \\
\hline Nutritional composition (\% DM) & D-60 & D0 & D42 \\
\hline Dry matter (DM) & 99.77 & 99.73 & 99.72 \\
Crude ash & 8.64 & 7.64 & 6.90 \\
Ethereal extract & 2.95 & 2.70 & 2.80 \\
Crude protein & 7.41 & 8.15 & 6.34 \\
Neutral detergent fiber & 72.13 & 67.96 & 74.05 \\
Acid detergent fiber & 64.60 & 39.99 & 43.91 \\
\hline
\end{tabular}

\section{Sample collection and processing}

During the experimental period, on the days 0 (D0, first vaccination), 21 (D21, second vaccination), and 42 (D42), blood samples were collected from all animals by puncture of the coccygeal arteriovenous complex through a vacutainer system with $25 \times 0.80$ $\mathrm{mm}$ needles and tubes containing clot activator. After collection, the samples were centrifuged at $400 \mathrm{x} g$ for 15 minutes and the serum was packed into $1.5 \mathrm{~mL}$ microtubes previously identified. Serum samples were placed in a water bath $\left(56^{\circ} \mathrm{C}\right)$ for 30 minutes for inactivation of the complement system and stored frozen at $-20{ }^{\circ} \mathrm{C}$ for further titration of neutralizing antibodies against BoHV-5 by means of the seroneutralization technique and determination of immunoglobulin ( $\mathrm{IgG}$ ) production against the glycoprotein D of bovine herpesvirus 5 (BoHV-5 $\mathrm{gD})$ envelope using the indirect ELISA technique (ARAUJO et al., 2018).

\section{Cells and viruses}

Cells of the MadinDarby BovineKidney(MDBK) strain were used for producing the vaccine antigen and in seroneutralization. Cells were maintained in Eagle's minimal essential medium (E-MEM Gibco $^{\circledR}$, Thermo Fisher Scientific, Waltham, USA), supplemented with $10 \%$ fetal bovine serum (FBS Gibco $^{\circledR}$, Thermo Fisher Scientific, Waltham, USA), 200 I.U. $\mathrm{mL}^{-1}$ streptomycin sulfate (Estreptomax ${ }^{\circledR}$, Ouro Fino Saúde Animal, Cravinhos, Brazil) and penicillin (Cristalpen ${ }^{\circledR}$, Biolab Farmacêutica, São

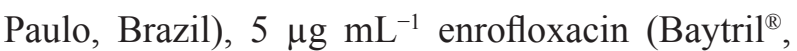
Bayer Animal Health, Leverkusen, Germany), and $2.50 \mu \mathrm{g} \mathrm{mL}^{-1}$ amphotericin $\mathrm{B}\left(\right.$ Unianf $^{\circledR}$, União Química, São Paulo, Brazil).

\section{Vaccines and inoculations}

The RP strain of bovine herpesvirus type 5 (BoHV-5) was isolated from a meningoencephalitis outbreak in Rio Grande do Sul, Brazil, and previously characterized (SIEDLER et al., 2012). The virus was used as a vaccine antigen and in the seroneutralization test. An aliquot of the virus, with a titer of $10^{7}$ TCID in $25 \mu \mathrm{L}$, was inactivated with 1\% 2-bromoethyl ammonium bromide $\left(\mathrm{C}_{2} \mathrm{H}_{7} \mathrm{Br}_{2} \mathrm{~N}\right.$, Merck, Darmstadt, Germany) at $0.02 \mathrm{M}$ 
concentration and $\mathrm{pH} 7.50$ for $12 \mathrm{~h}$ in a constant stirring at $4{ }^{\circ} \mathrm{C}$. The vaccine was synthesized by means of the emulsion between the viral suspension and oily adjuvant (Montanide ${ }^{\circledR}$ ISA 50 V2, SEPPIC, Paris, France) in a 1:1 ratio. On the days 0 (D0) and 21 (D21), animals from the control group CG01 were inoculated intramuscularly (IM) with $3 \mathrm{~mL}$ of $0.9 \%$ physiological solution to simulate the same management stress. Animals from the control group CG02 and from treatment groups TG01 and TG02 were IM inoculated with $3 \mathrm{~mL}$ of the experimental vaccine.

\section{Seroneutralization}

The titration of the serological levels of neutralizing antibodies conferred by the experimental vaccine was performed using the seroneutralization technique from serum samples. The samples were serially diluted in the 1:2 to 1:256 dilutions and distributed in a volume of $25 \mu \mathrm{L}$ in quadruplicate in 96-well microplates (Kasvi, São José dos Pinhais, Brazil) for subsequent addition of a suspension containing 100 TCID $_{50}$ BoHV-5. After an hour of incubation at $37{ }^{\circ} \mathrm{C}$ in a $5 \% \mathrm{CO}_{2}$ environment, $3 \mathrm{x}$ $10^{4}$ cells of the MDBK strain were added and the microplates incubated under the same conditions until the time of the $100 \mathrm{TCID}_{50}$ expression. The neutralizing antibody titer was calculated by the Behrends and Kärber method (MAYR et al., 1982).

\section{Indirect Elisa}

Detection of immunoglobulin ( $\mathrm{IgG})$ production against the glycoprotein $\mathrm{D}$ of bovine herpesvirus type 5 (BoHV-5 gD) envelope was performed by an indirect immunoenzymatic assay (ELISA). Polyvinyl chloride (PVC) flexible plates $\left(\right.$ Costar $^{\circledR}$, Corning Inc., Corning, USA) with 96 wells were sensitized for $1.5 \mathrm{~h}$ at $37{ }^{\circ} \mathrm{C}$ with $50 \mathrm{ng}$ BoHV$5 \mathrm{gD}$ per well, diluted in carbonate-bicarbonate buffer ( $\mathrm{pH}$ 9.60). The used antigen was kindly provided by the Laboratory of Bacteriology of the Center of Technological Development (CDTecUFPEL) and synthesized according to Dummer et al. (2009). After blocking for $1 \mathrm{~h}$ with 5\% skimmed milk powder and three washes with PBS-T, serum duplicates diluted 1:1600 were incubated for $1 \mathrm{~h}$ at $37{ }^{\circ} \mathrm{C}$. Fetal bovine serum (FBS Gibco ${ }^{\circledR}$, Thermo Fisher Scientific, Waltham, USA) was used as a negative control and serum of an animal previously vaccinated with a recombinant $\mathrm{BoHV}-5 \mathrm{gD}$ vaccine proved to be positive for BoHV-5 by means of the seroneutralization technique was used as a positive control. After three washes with PBS-T, the plates were incubated for $1.5 \mathrm{~h}$ with peroxidaseconjugated rabbit anti-bovine IgG antibody (SigmaAldrich, St. Louis, USA) diluted 1:10,000. After five washes with PBS-T, the reaction was developed with o-phenylenediamine dihydrochloride (OPD) (Sigma-Aldrich, St. Louis, USA) associated with hydrogen peroxide. A $2 \mathrm{M}$ sulfuric acid was used to block the reaction. The absorbance (492 nm) was measured in an ELISA reader (TP Reader ${ }^{\circledR}$, Thermo Plate, São Paulo, Brazil). The optimal dilutions of antigen, sera, and conjugate were determined by the checkerboard method.

\section{Statistical analysis}

The statistical analyses for body weight, MDG, BCS, neutralizing antibody titer, and absorbance in the indirect ELISA technique were performed using the repeated measures model Proc Mixed Models using the software SAS (SAS Institute Inc., Cary, USA). For this, group and date were used as fixed variables and body weight $(\mathrm{kg}), \mathrm{MDG}, \mathrm{BCS}$, neutralizing antibody titer $\left(\log ^{10}\right)$ and absorbance (OD $492 \mathrm{~nm}$ ) were used as response variables, with analysis of variance performed using the comparison model between groups, days, and interaction between groups and days. The data were analyzed considering the animals as the experimental unit. 


\section{Results and Discussion}

The experimental groups did not differ regarding body weight during the 102 days of supplementation
( $\mathrm{P} \geq 0.05)$, guaranteeing the homogeneity between groups during the entire period (Table 3).

Table 3. Average body weight, mean daily gain (MDG), and body condition score (BCS) at the end of the experiment according to the experimental group.

\begin{tabular}{lccccccc}
\hline & \multicolumn{3}{c}{ Groups } & \multicolumn{3}{c}{ P (Value) } \\
\cline { 2 - 7 } Parameter & CG01 & CG02 & TG01 & TG02 & Groups & Days & Groups*Days \\
\hline Body weight (kg) & 286.05 & 285.41 & 287.88 & 286.20 & 0.95 & $\leq 0.0001$ & 0.79 \\
MDG (kg) & 0.153 & 0.110 & 0.129 & 0.134 & 0.95 & $\leq 0.0001$ & $\leq 0.0001$ \\
BCS & 2.97 & 2.87 & 2.99 & 3.00 & 0.11 & 0.08 & $\leq 0.001$ \\
\hline
\end{tabular}

The results of seroneutralization analyses performed on serum samples from animals on the days 0 (D0), 21 (D21), and 42 (D42) in relation to the vaccine protocol were normalized in order to be expressed in logarithm $\left(\log ^{10}\right)$ and shown in Figure 1.

Figure 1. Neutralizing antibody titer on the days 0,21 , and 42 in relation to the vaccine protocol at the different evaluated groups. $* * \mathrm{P} \leq 0.0001$ compared to the non-vaccinated control group (CG01).

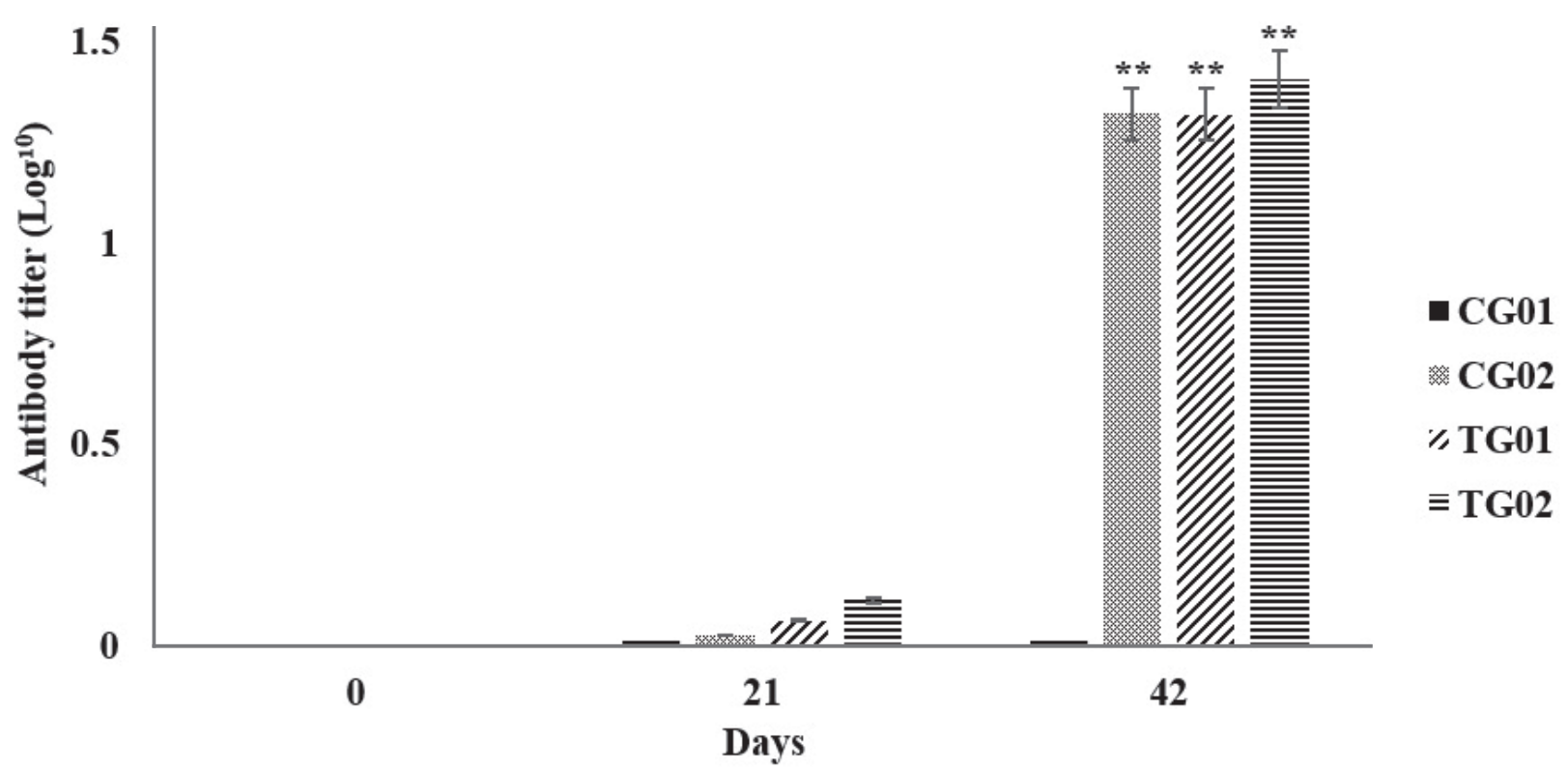

Table 4 shows the cumulative percentage distribution of antibody titers after 21 (D21) and 42 (D42) days in relation to the beginning of the vaccine protocol. As expected, no animals belonging to CG01 seroconverted throughout the experiment, guaranteeing the absence of a possible introduction of the agent (BoHV) in the studied area. When vaccinated animals were compared to the control group CG01, without vaccination, statistically higher levels of neutralizing antibodies were observed only 21 days after the second vaccine dose (D42) $(\mathrm{P} \leq 0.0001)$. 
Table 4. Cumulative percentage distribution of neutralizing antibody titers on the days 21 and 42 in relation to the vaccine protocol at the different evaluated groups.

\begin{tabular}{|c|c|c|c|c|c|c|c|c|}
\hline \multirow[b]{2}{*}{ Titer } & \multicolumn{3}{|c|}{$\mathrm{D} 21$} & \multirow[b]{2}{*}{ TG02 } & \multicolumn{3}{|c|}{ D42 } & \multirow[b]{2}{*}{ TG02 } \\
\hline & CG01 & CG02 & TG01 & & CG01 & CG02 & TG01 & \\
\hline $0-7.9$ & 0 & 16.60 & 41.60 & 25.00 & 0 & 100 & 100 & 100 \\
\hline $8-15.9$ & 0 & 0 & 0 & 8.30 & 0 & 83.30 & 83.30 & 83.30 \\
\hline $16-31.9$ & 0 & 0 & 0 & 8.30 & 0 & 50 & 66.60 & 66.60 \\
\hline$\geq 32$ & 0 & 0 & 0 & 0 & 0 & 33.30 & 33.30 & 41.60 \\
\hline
\end{tabular}

When comparing the supplemented and vaccinated groups, no difference $(\mathrm{P} \geq 0.05)$ was observed in the seroconversions against BoHV, regardless of the treatment. Antibody titrations at 21 days after the first dose (D21) did not present protective titers to the herd, with titers $\geq 2$ in only $16.60 \%(2 / 12)$ of the animals in CG02, $41.60 \%$ $(5 / 12)$ in TG01, and $25.00 \%(3 / 12)$ in TG02. The same 21-day interval for new collections (D42) was adopted after the second vaccine dose, resulting in a $100 \%$ seroconversion of vaccinated animals.

Brazilian regulatory agencies do not define a minimum level and percentage of seroconversion against BoHV to consider vaccine efficacy. However, when considering indications of regulatory agencies of the United States, the use of inactivated BoHV vaccines should provide a seroconversion in at least $80.00 \%$ of the animals, with neutralizing antibody titers $\geq 8$ (USDA, 2005). Thus, titers $\geq 8$ were shown in $83.30 \%(10 / 12)$ of the animals in CG02, $83.30 \%(10 / 12)$ in TG01, and $83.30 \%(10 / 12)$ in TG02. These results indicate the importance of booster vaccination and confirm the ability of the used experimental vaccine to stimulate the immune system, with a minimum period of 21 days after the second dose.

Compared to the present study, authors such as Spears et al. (1991) have demonstrated the benefits of zinc ( $\mathrm{Zn})$ supplementation to steers recently transplanted to a feedlot system and vaccinated with a live modified vaccine against bovine herpesvirus type 1 (BoHV-1) and parainfluenza type 3 (PI3), showing a significant increase of neutralizing antibodies against BoHV-1 at 14 days after the vaccine dose in animals supplemented with $\mathrm{Zn}$. No differences were observed regarding the antibody levels against PI3. In a second moment, the same group of researchers evaluated the effects of $\mathrm{Zn}$ supplementation and its relation to the immune response of growing steers, but without the same post-transport stress conditions. The humoral immune response was verified after vaccination against BoHV-1, but no differences were observed regarding antibody titers, regardless of the treatment (SPEARS et al., 2002). Therefore, the beneficial effects of an increase in $\mathrm{Zn}$ source on immune responses may be directly related to periods in which animals are submitted to stressful management, such as weaning and transport associated with arrival in feedlots, factors to which the heifers of this study were not exposed.

Hall et al. (2011) supplemented adult cows with selenium (Se) for 42 days, used a vaccine composed of bacterin of Escherichia coli J5, and determined increases in vaccine antibody titers. Calves fed alfalfa supplemented with $\mathrm{Se}$ and subjected to vaccination with bacterin of Escherichia coli J5 presented higher antibody titers and higher total antioxidant potential of neutrophils, in addition to lower mortality and higher slaughter weight at the end of confinement (HALL et al., 2013).

Immunoglobulin ( $\mathrm{IgG}$ ) levels induced by the experimental vaccine were measured by indirect ELISA with serum samples collected on the days 
0 (D0), 21 (D21), and 42 (D42) of the vaccine protocol. As observed in neutralizing antibody titers, measured by seroneutralization, IgG levels were significantly higher when compared to the non-vaccinated control group 21 days after the second vaccine dose (D42), as shown in Figure 2. When comparing the groups under treatment with supplementation, no significant differences $(\mathrm{P} \geq 0.05)$ were observed between CG02 (1.13 \pm 0.32$)$, TG01 $(0.89 \pm 0.38)$, and TG02 (1.05 \pm 0.39$)$.

Figure 2. Average absorbance on the days 0, 21, and 42 in relation to the vaccine protocol at the different evaluated groups through indirect ELISA for the detection of immunoglobulins (IgG) against BoHV-5 gD. **P $\leq 0.0001 \mathrm{compared}$ to the non-vaccinated control group (CG01).

\section{5}

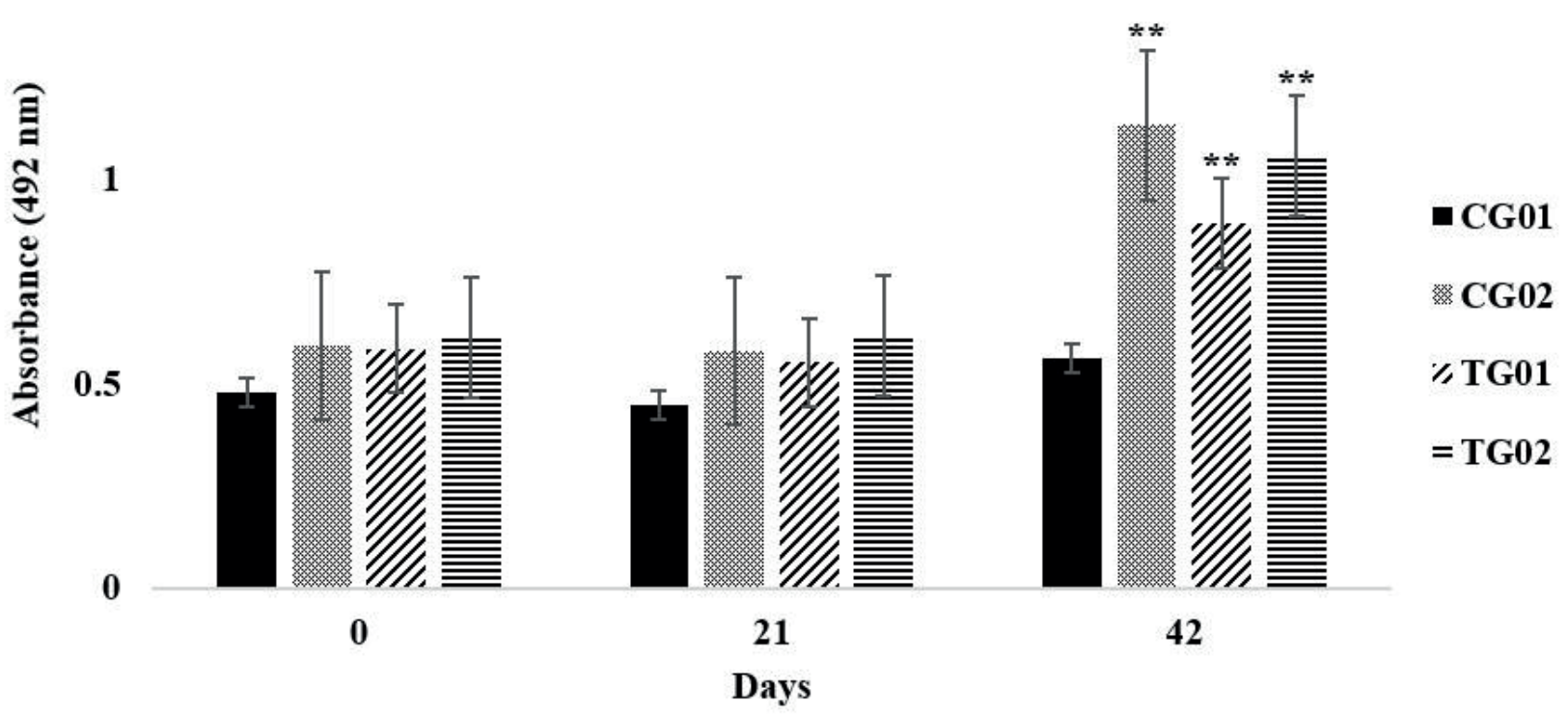

Copper $(\mathrm{Cu})$ is another pointed micro-mineral with direct influences on the performance of the immune system. Authors such as Cerone et al. (1995) worked with the induction of decreased levels of $\mathrm{Cu}$ and ceruloplasmin in heifers and challenged them by vaccination against Brucella abortus, obtaining lower total immunoglobulin (IgG) levels.

Nemec et al. (2012) also evaluated the immune response in dairy cows supplemented with different sources of $\mathrm{Cu}, \mathrm{Mn}$, and $\mathrm{Zn}$. This study compared the effects of presentation forms on inorganic sulfates and presentations protected by chelates and subjected the animals to a rabies vaccination protocol. Cows supplemented with organic forms of minerals presented higher concentrations of antibodies and higher phagocytic capacity of neutrophils when compared to the group of animals supplemented with inorganic forms of minerals. These results may indicate that the inorganic forms of mineral presentation in our experiment, as in the work cited above, have been interfered with in the bioavailability, a reduced risk when minerals are supplied complexed with amino acids, for example, reducing the risks of antagonisms between the efficiency of absorption of these nutrients and micro-minerals (SWECKER, 2014). In this sense, our study was not able to guarantee integrality in the absorption of supplemented elements since serum doses of the proposed minerals and amino acids were not performed. Recent studies using the same source of rumen-protected methionine used in our experiment ensured significantly higher levels of plasma methionine in dairy cows supplemented for at least 21 days (ZANG et al., 2017; ZHOU et al., 2017; WEISS, 2019). 
This study was based on specific serological response analyses, such as the production of neutralizingantibodiesand specificimmunoglobulins G, exactly 21 days after each vaccination. Other key indicators for the development of an efficient humoral immune response, such as the production of cytokines or immediate responses in the process of recognition and presentation of antigens, such as mediators of innate immune response, have not been evaluated. The recent literature does not correlate the effects of protected methionine supplementation with the humoral immune response in cattle. The hypothesis of this study was elaborated based on studies that proved the potential of this amino acid in the responses in lymphocyte proliferation (SODER; HOLDEN, 1999) and increase of important cytokines that modulate the immunoglobulin pattern to be secreted by plasmocytes, such as the interleukin-6 (IL-6), significantly increased in challenging situations in dairy cows (VAILATI-RIBONI et al., 2017; ZHOU et al., 2016). In addition, studies carried out with other species advocate the increase of circulating methionine as a way to stimulate immunoglobulin production after vaccination protocols. The increase in antibody titers was verified in broiler chickens vaccinated against Gumboro disease by Jahanian and Khalifeh-Gholi (2018). Similarly, supplementation with high methionine doses provided an increase in antibody titers in young turkeys vaccinated against Ornithobacterium rhinotracheale, with an increased percentage of TCD4 and TCD8 lymphocytes in lymphoid organs (KUBINSKA et al., 2015). In mammals, studies such as those of Jiao et al. (2016) found an increase in the total concentrations of the immunoglobulins $\operatorname{IgG}$ and $\operatorname{IgA}$ in finishing pigs supplemented with low protein diets and enriched with a combination of amino acids based on lysine, threonine, tryptophan, valine, and methionine. Understanding the limitations and differences imposed by phylogenetic distances between species, we should consider that mechanisms of cellular and molecular regulation could be extrapolated within the communication pathways of the immune system. This context, coupled with the lack of researches that correlate this type of supplement with adaptive immunity in ruminants, allows a long path that can still be explored.

\section{Conclusions}

The results presented in this study allow concluding that, in relation to the evaluated immunological parameters, the higher contribution of minerals or methionine did not contribute to an increase of the seroconversion in vaccinated animals, with no differences in neutralizing antibodies and in specific immunoglobulins.

\section{References}

ARAUJO, I. L.; DUMMER, L.A.; RODRIGUES, P. R. C.; SANTOS JUNIOR, A. G. dos; FISCHER, G.; CUNHA, R. C.; LEITE, F. P. L. Immune responses in bovines to recombinant glycoprotein D of bovine herpesvirus type 5 as vaccine antigen. Vaccine, Kidlington, v. 36, n. 50, p. 7708-7714, 2018. DOI: 10.1016/j.vaccine.2018.10.080

CERONE, S. I.; SANSINANEA, A. S.; AUZA, N. J. Copper deficiency alters the immune response of bovine. Nutrition Research, New York, v. 15, n. 9, p. 1333-1341, 1995. DOI: $10.1016 / 0271-5317(95) 02008-J$

CLEMENTS, A. R.; IRELAND, F. A.; FREITAS, T.; TUCKER, H.; SHIKE, D. W. Effects of supplementing methionine hydroxy analog on beef cow performance, milk production, reproduction, and preweaning calf performance. Journal of Animal Science, Champaign, v. 95 , n. 12 , p. $5597-5605$, 2017. DOI: $10.2527 /$ jas 2017.1828

DUMMER, L. A.; CONCEIÇÃO, F. R.; NIZOLI, L. Q.; MORAES, C. M.; ROCHA, A. R.; SOUZA, L. L.; ROOS, T.; VIDOR, T.; LEITE, F. P. Cloning and expression of a truncated form of envelope glycoprotein D of Bovine herpesvirus type 5 in methylotrophic yeast Pichia pastoris. Journal of Virological Methods, Amsterdam, v. 161, n. 1, p. 84-90, 2009. DOI: 10.1016/j. jviromet.2009.05.022

HALL, J. A.; BOBE, G.; VORACHEK, W. R.; HUGEJILETU.; GORMAN, M. E.; MOSHER, W. D.; PIRELLI, G. J. Effects of feeding selenium-enriched alfalfa hay on immunity and health of weaned beef calves. Biological Trace Element Research, Clifton, v. 156, n. 1-3, p. 96-110, 2013. DOI: 10.1007/s12011-013-9843-0 
HALL, J. A.; HARWELL, A. M.; VAN SAUN, R. J.; VORACHEK, W. R.; STEWART, W. C.; GALBRAITH, M. L.; HOOPER, K. J.; HUNTER, J. K.; MOSHER, W. D.; PIRELLI, G. J. Agronomic biofortification with selenium: effects on whole blood selenium and humoral immunity in beef cattle. Animal Feed Science and Technology, Amsterdam, v. 164, n. 3, p. 184-190, 2011. DOI: 10.1016/j.anifeedsci.2011.01.009

JAHANIAN, R.; KHALIFEH-GHOLI, M. Marginal dificiencies of dietary arginine and methionine could suppress growth performance and immunological responses in broiler chickens. Journal of Animal Physiology and Animal Nutrition, Berlin, v. 102, n. 1, p. e11-e20, 2018. DOI: 10.1111/jpn.12695

JIAO, X.; MA, W.; CHEN, Y.; LI, Z. Effects of amino acids supplementation in low crude protein diets on growth performance, carcass traits and serum parameters in finishing gilts. Animal Science Journal, Sendai v. 87, n. 10 , p. $1252-1257,2016$. DOI: 10.1111/asj. 12542

KUBINSKA， M.; TYKALOWSKI，B.; KONCICKI, A.; JANKOWSKI, J. Biochemical and immunological responses of young turkeys to vaccionation against Ornithobacterium rhinotracheale and different levels of dietary methionine. Polish Journal of Veterinary Sciences, Olsztyn, v. 18, n. 4, p. 807-816, 2015. DOI: 10.1515/pjvs-2015-0105

LOWMAN, B. G.; SCOTT, N.; SOMERVILLE, S. Condition scoring beef cattle. In: LOWMAN, B. G.; SCOTT, N.; SOMERVILLE, S. East of scotland college of agriculture. Edinburgh, EB: Edinburgh School of Agriculture. 1973.

MANDAL, G. P.; DASS, R. S.; ISORE, D. P.; GARG, A. K.; RAM, G. C. Effect of zinc supplementation from two sources on growth, nutrient utilization and immune response in male crossbred cattle (Bos indicus x Bos taurus) bulls. Animal Feed Science and Technology, Amsterdam, v. 138, n. 1, p. 1-12, 2007. DOI: 10.1016/j. anifeedsci.2006.09.014

MAYR, A.; BACHMANN, P. A.; BIBRACK, B. M.; WITHMANN, G. Virologische Arbeitsmethoden Sicherheit bei virologischen arbeiten - Biomestrische Methoden. Stutgart, ST: Gustav Fischer Verlag, 1982.

McMENIMAN, N. P. Methods of estimating intake of grazing animal. REUNIÃO ANUAL DA SOCIEDADE BRASILEIRA DE ZOOTECNIA, 1997, Juiz de Fora, MG. Anais... Juiz de Fora, MG: Sociedade Brasileira de Zootecnia, 1997. p. 131.

NEMEC, L. M.; RICHARDS, J. D.; ATWELL, C. A.; DIAZ, D. E.; ZANTON, G. I.; GRESSLEY, T. F. Immune responses in lactating Holstein cows supplemented with $\mathrm{Cu}, \mathrm{Mn}$, and $\mathrm{Zn}$ as sulfates or methionine hydroxy analogue chelates. Journal Dairy Science, Champaign, v. 95, n. 8, p. 4568-4577, 2012. DOI: 10.3168/jds.2012-5404

OSORIO, J. S.; JI, P.; DRACKLEY, J. K.; LUCHINI, D.; LOOR, J. J. Supplemental Smartamine M or MetaSmart during the transition period benefits postpartal cow performance and blood neutrophil function. Journal Dairy Science, Champaign, v. 96, n. 10, p. 6248-6263, 2013. DOI: $10.3168 /$ jds.2012-5790

PAUL, S. S.; DEY, A. Nutrition in health and immune function of ruminantes. Indian Journal of Animal Sciences, New Delhi, v. 2, n. 85, p. 103-112, 2015.

SANTOS, M. E. R.; FONSECA, D. M.; EUCLIDES, V. P. B.; RIBEIRO JUNIOR, J. I. R.; NASCIMENTO JUNIOR, D. N.; MOREIRA, L. M. Produção de bovinos em pastagens de capim-braquiária diferidas. Revista Brasileira de Zootecnia, Viçosa, MG, v. 38, n. 4, p. 635642, 2009. DOI: $10.1590 /$ S1516-35982009000400007

SIEDLER, B. S. Avaliação de uma vacina de aplicação intravaginal contra o Herpesvirus bovino tipo 5 (BoHV-5) associada a subunidade $B$ recombinante da enterotoxina Termolábil de Escherichia coli (rLTB). 2012. Dissertação (Mestrado em Ciências) - Faculdade de Veterinária, Universidade Federal de Pelotas, Pelotas.

SODER, K. J.; HOLDEN, L. A. Lymphocyte proliferation response of lactating dairy cows fed varying concentrations of rumen-protected methionine. Journal Dairy Science, Champaign, v. 82, n. 9, p. 1935-1942, 1999. DOI: $10.3168 /$ jds.S0022-0302(99)75429-9

SPEARS, J. W.; HARVEY, R. W.; BROWN, T. T. Effects os zinc methionine and zinc oxide on performance, blood characteristics, and antibody titer response to viral vaccination in stressed feeder calves. Journal of the American Veterinary Medical Association, Chicago, v. 199, n. 12, p. 1731-1733, 1991.

SPEARS, J. W.; KEGLEY, E. B. Effect of zinc source (zinc oxide vs zinc proteinate) and level on performance, carcass characteristics, and immune response of growing and finishing steers. Journal of Animal Science, Champaign, v. 80 , n. 10 , p. $2747-2752$, 2002. DOI: $10.2527 / 2002.80102747 \mathrm{x}$

SWECKER, W. S. Trace mineral feeding and assessment. The Veterinary Clinics of North America. Food Animal Practice, Philadelphia, v. 30, n. 3, p. 671-688, 2014. DOI: 10.1016/j.cvfa.2014.07.008

UNITED STATES DEPARTMENT OF AGRICULTURE - USDA, Animal and plant health inspection service. USDA, 2005. p. 683-684. Disponível em: https://www. govinfo.gov/content/pkg/CFR-2012-title9-vol1/pdf/ CFR-2012-title9-vol1-sec113-216.pdf. Acesso em: 05 abr. 2019. 
VAILATI-RIBONI, M.; ZHOU, Z.; JACOMETO, C. B.; MINUTI, A.; TREVISI, E.; LUCHINI, D. N.; LOOR, J. J. Supplementation with rumen-protected methionine or choline during the transition period influences wholeblood immune response in periparturient dairy cows. Journal of Dairy Science, Champaign, v. 100, n. 5, p. 3958-3968, 2017. DOI: 10.3168/jds.2016-11812

WATERMAN, R. C.; UJAZDOWSKI, V. L.; PETERSEN, M. K. Effects of rumen-protected methionine on plasma amino acid concentrations during a period of weight loss for late gestating beef heifers. Amino Acids, Wien, v. 43, n. 5 , p. $2165-2177,2012$. DOI: $10.1007 / \mathrm{s} 00726-012-$ 1301-3

WEISS, W. P. Effects of feeding diets composed of corn silage and a corn milling product with and without supplemental lysine and methionine to dairy cows. Journal of Dairy Science, Champaign, v. 102, n. 3, p. 2075-2084, 2019. DOI: 10.3168/jds.2018-15535

ZANG, Y.; SAMII, S. S.; PHIPPS, Z. C.; TAGER, L. R.; McFADDEN, J. W.; KRAUSE, K. M. Comparative effects of multiple sources of rumen-protected methionine on milk production and serum amino acid levels in midlactation dairy cows. The Professional Animal Scientist, Michigan, v. 33, n. 6, p. 692-699, 2017. DOI: 10.15232/ pas.2017-01641
ZHOU, Z.; BULGARI, O.; VAILATI-RIBONI, M.; TREVISI, E.; BALLOU, M. A.; LUCHINI, D. N.; LOOR, J. J. Rumen-protected methionine compared with rumen-protected choline improves immunometabolic status in dairy cows during the peripartal period. Journal of Dairy Science, Champaign, v. 99, n. 11, p. 8956-8969, 2016. DOI: $10.3168 /$ jds.2016-10986

ZHOU, Z.; FERDOUS, F.; MONTAGNER, P.; LUCHINI, D. N.; CORRÊA, M. N.; LOOR, J. J. Methionine and choline supply during the peripartal period alter polymorphonuclear leukocyte immune response and immunometabolic gene expression in Holstein cows. Journal of Dairy Science, Champaign, v. 101, n. 11, p. 10374-10382, 2018. DOI: $10.3168 / j d s .2018-14972$

ZHOU, Z.; VAILATI-RIBONI, M.; LUCHINI, D. N.; LOOR, J. J. Methionine and choline supply during the periparturient period alter plasma amino acid and onecarbon metabolism profiles to various extents: potential role in hepatic metabolism and antioxidant status. Nutrients, Basel, v. 9, n. 10, p. 1-19, 2017. DOI: 10.3390/ nu9010010 